\title{
Effect of cadmium on the floor of the mouth on rats during lactation
}

\section{Efeito do cádmio no soalho da boca de ratos durante a lactação}

\author{
Lara Cristina Picoli* \\ Ii-Sei Watanabe** \\ Ruberval Armando Lopes*** \\ Miguel Angel Sala*** \\ Fábio Picoli****
}

\begin{abstract}
Cadmium (Cd) present in the air, drinking water and food has the potential to affect the health of people, mainly those who live in highly industrialized regions. Cd affects placental function, may cross the placental barrier and directly modify fetal development. It is also excreted into milk. The body is particularly susceptible to $\mathrm{Cd}$ exposure during perinatal period. The effect on rat oral epithelium (floor of the mouth) after continuous exposure to drinking water containing low levels of $\mathrm{Cd}$ during lactation was studied. Female rats were supplied with ad libitum drinking water containing $300 \mathrm{mg} / 1$ of $\mathrm{CdCl}_{2}$ throughout the whole lactation period. Control animals received a similar volume of water without $\mathrm{Cd}$. Lactating rats ( 21 day-old) were killed by lethal dose of anesthetic. The heads were retrieved, fixed in "alfac" solution (alcohol, acetic acid and formaldehyde) for $24 \mathrm{~h}$, serially sectioned in frontal plane, at the level of the first molars. The $6 \mu \mathrm{m}$ sections were then stained with hematoxylin and eosin. Nuclear epithelium parameters were estimated, as well as cytoplasm and cell volume, nucleus/cytoplasm ratio, numeric and surface densities, and epithelial thickness. Mean body weight was $34.86 \mathrm{~g}$ for the control group and $18.56 \mathrm{~g}$ for the Cd-treated group. Histologically, the floor of the mouth epithelium was thinner in the treated group, with smaller and more numerous cells. In this experiment, Cd induced epithelial hypotrophy, indicating a direct action in oral mucosa cells, besides retarded development of the pups.
\end{abstract}

DESCRIPTORS: Mouth mucosa; Microscopy, polarization; Cadmium; Morphometry; Stereology.

RESUMO: O cádmio (Cd) do ar, da água e dos alimentos tem o potencial de afetar a saúde das pessoas, principalmente daquelas que vivem em regiões altamente industrializadas. O Cd afeta a função placentária, podendo atravessar a barreira placentária e provocar distúrbios no desenvolvimento fetal. Pode, também, ser excretado pelo leite. O organismo é particularmente susceptivel à exposição ao $\mathrm{Cd}$ no período perinatal. Foi estudado o efeito da intoxicação por $\mathrm{Cd}$ no epitélio do soalho da boca de ratos expostos a baixos níveis do metal na água de bebedouro, durante a lactação. As ratas receberam água ad libitum contendo $300 \mathrm{mg} / 1 \mathrm{de} \mathrm{CdCl}_{2}$ durante toda a lactação. Os animais controle receberam um volume similar de água sem $\mathrm{Cd}$. Os filhotes foram sacrificados por sobredosagem anestésica no $21^{\circ}$ dia. As cabeças dos animais foram separadas, fixadas em solução de "alfac" (álcool, ácido acético e formaldeído) por $24 \mathrm{~h}$, seccionadas seriadamente em planos frontais ao nivel dos primeiros molares, e os cortes de $6 \mu \mathrm{m}$ foram corados com hematoxilina-eosina. Foram estimados os parâmetros nucleares do epitélio, assim como os volumes citoplasmático e celular, a relação núcleo/citoplasma, as densidades numérica e superficial e a espessura epitelial. O peso corporal médio do filhote foi de $34,86 \mathrm{~g}$ no grupo controle e $18,56 \mathrm{~g}$ no tratado. Histologicamente, o epitélio dos animais tratados mostrou-se adelgaçado, constituído de células abundantes e menores. Neste experimento, o Cd ocasionou um quadro de hipotrofia epitelial, indicando uma ação direta nas células epiteliais da mucosa oral, além de retardar o desenvolvimento dos filhotes intoxicados.

DESCRITORES: Mucosa bucal; Microscopia de polarização; Cádmio; Morfometria; Estereologia.

\footnotetext{
* Professor, Department of Health, Discipline of Morphology, School of Dentistry, University Nove de Julho.

** Professor, Department of Anatomy, Discipline of Anatomy, Biomedical Science Institute; ***Professors, Department of Morphology, Stomatology and Physiology, Discipline of Diagnosis II and III, School of Dentistry of Ribeirão Preto - University of São Paulo.

**** Professor, Department of Endodontics, School of Dentistry, University of Franca.
} 
Picoli LC, Watanabe I, Lopes RA, Sala MA, Picoli F. Effect of cadmium on the floor of the mouth on rats during lactation. Braz Oral Res 2004;18(2):105-9.

\section{INTRODUCTION}

At present, Cadmium is considered one of the major environmental pollutants due to its extensive use in industry and to its long biological halflife. Animal studies have shown that the highest cadmium levels after a single intravenous injection of $\mathrm{CdCl}_{2}$ (109 cadmium) were found in the liver and kidney, and also in the pancreas and salivary glands in mice ${ }^{1}$. During pregnancy, cadmium is retained in the placenta, which acts as an important, but not complete, barrier to protect the fetus from cadmium exposure. It has been shown in rodents ${ }^{27}$ as well as in humans ${ }^{12}$. Cadmium transfer via milk is reported to be low in rats and mice, which might be due to the binding of cadmium to metallothionein in the mammary tissue ${ }^{17}$. Metallothioneins are a group of low-molecular-weight, highly inducible proteins that maintain intracellular zinc homeostasis and protect against cadmium-induced hepatotoxicity ${ }^{24}$.

Since the toxic effects of pollutants are often correlated with their concentration in individual tissues and organs, the purpose of the present investigation was to study the effects of cadmium on the epithelium of the floor of the mouth of the rat, during lactation.

\section{MATERIAL AND METHODS}

Female Wistar rats were mated and kept in separate cages. Standard pellet diet (Purina, Nuvital, Colombo, PR, Brazil) and tap water were given ad libitum. On the day of parturition, defined as day 1 , the litters were reduced to eight pups. Cadmium was administered in the drinking water $(300 \mathrm{mg} / 1$ of $\mathrm{CdCl}_{2}$, Carlo Erba Reagenti, Milano, Italy) during 21 days (lactation). All pups were sacrificed with $3 \%$ Hypnol (3\% sodium pentobarbital, Fonto Veter, São Paulo, Brazil) at the end of day 21. The heads were separated from the bodies, fixed in a fixative solution consisting of $85 \mathrm{ml}$ of $80 \%$ ethanol, $10 \mathrm{ml}$ of formalin and $5 \mathrm{ml}$ of glacial acetic acid, for $24 \mathrm{~h}$, embedded in paraffin, cut frontally into semi-serial $6 \mu \mathrm{m}$ thick sections and stained with hematoxylin and eosin.

The following karyometric parameters of the different layers of the floor of the mouth epithelium were estimated according to Sala et al. ${ }^{18}$ (1994): the longest axis (D), the shortest axis (d), geometric mean axis, ratio of the longest to the shortest axis $(\mathrm{D} / \mathrm{d}$ ratio), perimeter, area, volume, ratio of volume to area (V/A ratio), shape factor, contour index and eccentricity.

The following stereologic parameters of the different layers of the floor of the mouth epithelium were determined: cytoplasmic volume, cell volume, nucleus/cytoplasm ratio and cell number density, epithelial surface density and thickness of the epithelium and of the keratin layer ${ }^{19}$.

Data were analyzed statistically by the MannWhitney's non-parametric test.

\section{RESULTS}

The pups from dams that had received cadmium during lactation showed significantly lower ( $p<0.01)$ body weight $(18.56 \mathrm{~g})$ than the control pups (34.86 g).

Histopathological analysis revealed that the lining epithelium of the floor of the mouth of treated pups was thinner and consisted of basal, spinous and granulous cells of smaller volume. The number of cells per $\mathrm{mm}^{3}$ had greatly increased, and the keratin layer was thinner (Figures 1 and 2).

The general measurements of the nuclei (longest, shortest and mean axis, perimeter, area, volume and V/A ratio) of cells of the basal and spinous layers of the floor of the mouth showed a statistically significant reduction in the treated group. The eccentricity, contour index and shape factor of the nuclei showed similar values (Table 1).

The cytoplasm and cell volumes, the nucleus / cytoplasm ratio and the thickness of basal cells and spinous cells layers were significantly reduced in the floor of the mouth. The cell number density of both layers was significantly increased in treated pups (Table 2).

The epithelium and keratin were thinner in treated pups $(\mathrm{p}<0.01)$. The surface density, outer/inner surface ratio and cell numerical density showed significantly higher values in treated pups (Table 2).

\section{DISCUSSION}

In this study, a significant lower body weight of pups of animals intoxicated with cadmium was observed. Reduced pup weight was also observed in rats by Crowe, Morgan ${ }^{6}$ (1997), in mice by Whelton et al. ${ }^{28}$ (1988), and in newborn lambs by Floris et al. $^{7}$ (2000).

Cadmium has a major influence on calcium metabolism ${ }^{9}$. Low dietary calcium induces synthesis of a calcium-binding protein which increases 
Picoli LC, Watanabe I, Lopes RA, Sala MA, Picoli F. Effect of cadmium on the floor of the mouth on rats during lactation. Braz Oral Res 2004;18(2):105-9.

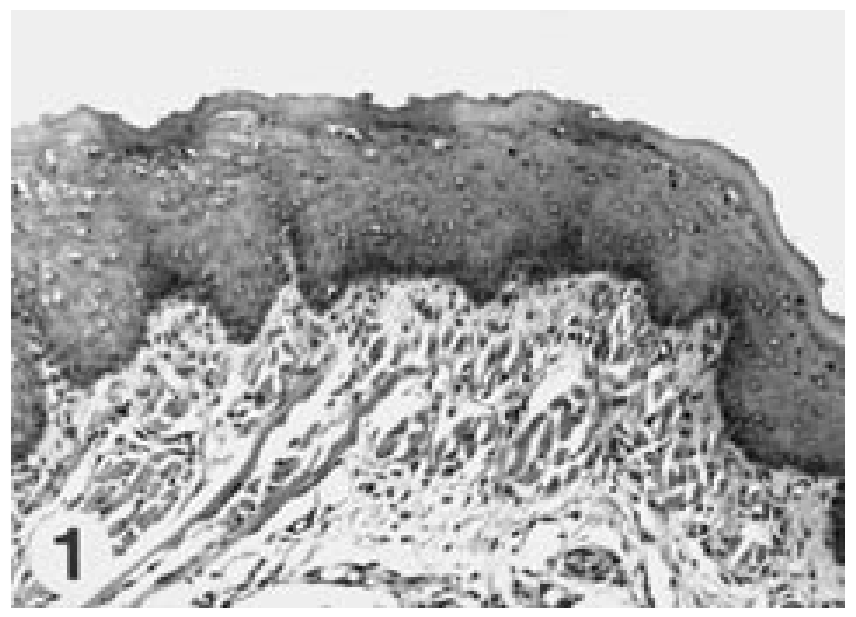

FIGURE 1 - Micrography showing floor of the mouth epithelium of the control rat. (H. E., $360 \mathrm{X}$ ).

cadmium absorption ${ }^{9}$ and consequently reduces body weight gain. Increased dietary intake of both iron and cadmium was accompanied by impaired growth rate. In the case of cadmium, growth restriction is considered to be an effect of the toxicity of the metal ${ }^{3}$.

In this study, the epithelium of the floor of the mouth of intoxicated pups was thinner, with smaller and more numerous cells, characterizing cellular hypotrophy.

The histometric data shows that the epithelium of the floor of the mouth was thinner in treated pups. The cellular layers were thinner, with numerous small cells, as observed after stereology, when it was possible to observe a reduced total epithelium thickness, associated with higher surface density, as well as small cytoplasm and cell volumes with a significantly larger cell number density. The nuclei were smaller in the basal layer, as observed by the lower values for the longest, smallest and mean diameters, perimeter, area, volume and V/A ratio. The nuclear shape was not altered, as demonstrated by similar values for eccentricity, shape factor and contour index. The spinous layer was similar to the basal one. The granulous and keratin layers were thinner.

Cadmium is toxic to cellular processes by disrupting mitochondrial function ${ }^{14}$ and can interfere with the transportation and metabolism of many essential metals, such as iron, copper and zinc ${ }^{4}$. Adequate availability of both zinc and copper is essential for normal growth and development. Insufficient zinc availability in fetal or early postnatal life retards growth ${ }^{20}$. Cadmium directly inter-

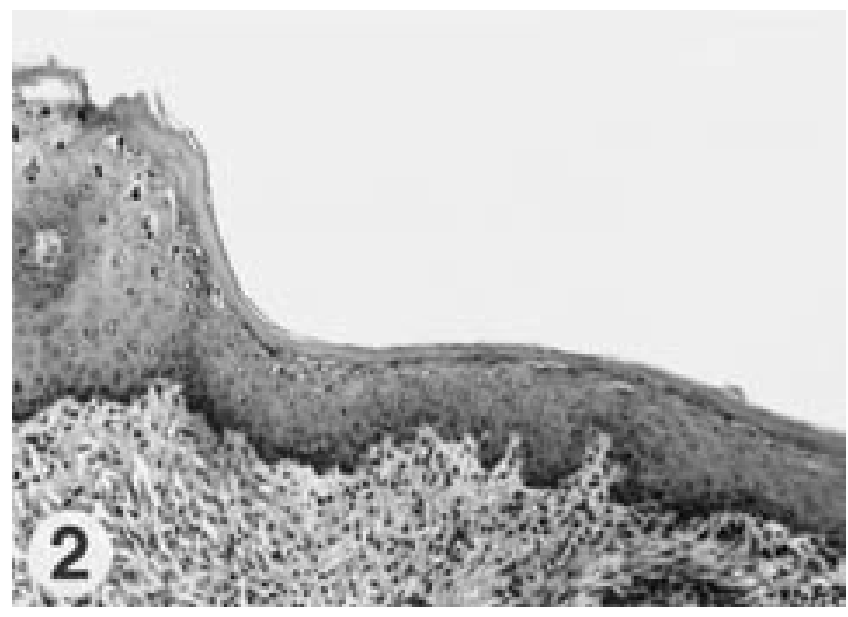

FIGURE 2 - Micrography showing floor of the mouth epithelium of the treated rat. Note the inner epithelium, with smaller and more numerous cells. (H. E., $360 \mathrm{X}$ ).

feres with iron absorption through the intestine, possibly by competing with iron in the absorptive process ${ }^{21}$, and inducing iron-deficiency anemia. Crowe, Morgan ${ }^{6}$ (1997) observed that this anemia begins during the nursing period, retarding growth of the pups.

Cadmium is found bound to metallothionein (MT) in the liver. Concentrations of MT can be found in the liver of mice in the postnatal period ${ }^{29}$. Lucis et al. ${ }^{13}$ (1972) found significant levels of cadmium in the liver and intestines of the neonate. The neonatal intestine accumulated increasing amounts of cadmium with time, containing 17 times more cadmium than the liver after 11 days of lactation.

Cadmium exposure in postnatal life induced Cd-MT synthesis and consequent displacement of zinc and copper of the MT channels ${ }^{16}$. When the metal exceeds the amount of MT, it begins its toxicant effects, as observed in this paper.

The perfusion of isolated hepatic systems as well as in vitro studies showed that cadmium inhibits the synthesis of proteins. It also interfers in mRNA transcription binding with specific sites of chromatine. Cadmium breaks up polyribosomic structures ${ }^{8}$ increasing the effect on mRNA transcription and, finally, it leads to peroxidation in lipids ${ }^{23}$ which can affect the synthesis of excretory proteins.

Cadmium in excess or free in cytoplasm binds with cell organelles and with nuclei, altering their function. Cadmium is also a genotoxic that causes DNA to break up, leading ${ }^{5}$ to mutations ${ }^{2}$ and chro- 
Picoli LC, Watanabe I, Lopes RA, Sala MA, Picoli F. Effect of cadmium on the floor of the mouth on rats during lactation. Braz Oral Res 2004;18(2):105-9.

TABLE 1 - Karyometric parameters of epithelial cells of the floor of the mouth in control (C) and cadmiumintoxicated (I) pups. Mann-Whitney test.

\begin{tabular}{l|r|r|r|r}
\hline \multirow{2}{*}{\multicolumn{1}{c|}{ Parameter }} & \multicolumn{2}{|c|}{ Basal layer } & \multicolumn{2}{c}{ Spinous layer } \\
\cline { 2 - 5 } & \multicolumn{1}{c|}{$\mathrm{C}$} & \multicolumn{1}{c}{$\mathrm{I}$} & \multicolumn{1}{c}{$\mathrm{C}$} & \multicolumn{1}{c}{$\mathrm{I}$} \\
\hline Longest axis $(\mu \mathrm{m})$ & 8.38 & $6.59^{*}$ & 9.68 & $8.03^{*}$ \\
\hline Shortest axis $(\mu \mathrm{m})$ & 6.19 & $5.01^{*}$ & 7.12 & $5.66^{*}$ \\
\hline Mean axis $(\mu \mathrm{m})$ & 7.18 & $5.72^{*}$ & 8.27 & $6.71^{*}$ \\
\hline $\mathrm{D} / \mathrm{d}$ ratio & 1.37 & 1.33 & 1.38 & 1.44 \\
\hline Perimeter $(\mu \mathrm{m})$ & 23.05 & $18.34^{*}$ & 26.60 & $21.72^{*}$ \\
\hline Area $\left(\mu \mathrm{m}^{2}\right)$ & 40.81 & $26.11^{*}$ & 54.17 & $35.81^{*}$ \\
\hline Volume $\left(\mu \mathrm{m}^{3}\right)$ & 198.53 & $102.46^{*}$ & 302.91 & $163.69^{*}$ \\
\hline V/A ratio & 4.79 & $3.81^{*}$ & 5.51 & $4.48^{*}$ \\
\hline Shape factor & 0.96 & 0.96 & 0.95 & 0.94 \\
\hline Contour index & 3.62 & 3.61 & 3.63 & 3.65 \\
\hline Eccentricity & 0.62 & 0.57 & 0.62 & 0.66 \\
\hline \hline
\end{tabular}

* Statistically significant at $\mathrm{p}<0.01$. D/d ratio: ratio of the longest to the shortest axis. V/A ratio: ratio of volume to area.

mosomic aberrations ${ }^{10}$. It acts on genes playing multiple roles in apoptosis ${ }^{30}$.

Cadmium is also known to cause adverse effects on numerous and important cell processes from lead metabolism interruption to the eventual death of cells ${ }^{15}$. Cd has high affinity for membranes of the sulfhydryl group ${ }^{11}$ which may account for the cell membrane disorganization ${ }^{25}$. Cadmium inhibits $\mathrm{Na}^{+} / \mathrm{K}^{+}$-ATPase ${ }^{11}$ as well as $\mathrm{Ca}^{2+}$-ATPase leading to an increase in intracellular calcium concentration $^{25,26}$. Vorbrodt et al. ${ }^{26}$ (1994) showed that cadmium inhibits $\mathrm{Ca}^{2+}$-ATPase in endothelial cell cultures and is specifically pronounced in the interendothelial fissures, that are junctional formation sites.

Calcium interacts with many heavy metals ${ }^{22}$ and may be an important factor in pathophysiologic mechanisms. The increase in intracellular calcium concentration caused by cadmium results from an increase in permeability in the plasmic membrane demonstrated in the $\mathrm{Ca}^{2+}$-ATPase inhibition mediated by calcium efflux ${ }^{25}$. These facts may account for the results observed in this study.

\section{REFERENCES}

1. Berlin $\mathrm{M}$, Ullberg $\mathrm{S}$. The fate of $\mathrm{Cd}^{109}$ in the mouse. Arch Environ Health 1963;21:686-93.
TABLE 2 - Mean stereological parameters of the floor of the mouth epithelium in control and cadmium-intoxicated pups. Mann-Whitney test.

\begin{tabular}{|c|c|c|}
\hline Parameter & Control & Intoxicated \\
\hline \multicolumn{3}{|c|}{ Basal layer } \\
\hline Cytoplasm volume $\left(\mu \mathrm{m}^{3}\right)$ & 149.58 & $97.04 * *$ \\
\hline Cell volume $\left(\mu \mathrm{m}^{3}\right)$ & 343.74 & 195.36* \\
\hline Nucleus/cytoplasm ratio & 0.34 & $0.25^{* *}$ \\
\hline Thickness $(\mu \mathrm{m})$ & 10.29 & $7.33^{*}$ \\
\hline Number density $\left(\mathrm{n} / \mathrm{mm}^{3} \times 10^{6}\right)$ & 2.97 & $5.22^{*}$ \\
\hline \multicolumn{3}{|c|}{ Spinous layer } \\
\hline Cytoplasm volume $\left(\mu \mathrm{m}^{3}\right)$ & 556.36 & $297.05^{*}$ \\
\hline Cell volume $\left(\mu \mathrm{m}^{3}\right)$ & 853.59 & $455.99 *$ \\
\hline Nucleus/cytoplasm ratio & 0.20 & $0.18^{* *}$ \\
\hline Thickness $(\mu \mathrm{m})$ & 19.24 & $11.53^{*}$ \\
\hline Number density $\left(\mathrm{n} / \mathrm{mm}^{3} \times 10^{6}\right)$ & 1.18 & $2.21^{*}$ \\
\hline \multicolumn{3}{|c|}{ Total epithelium } \\
\hline Surface density $\left(\mathrm{mm}^{2} / \mathrm{mm}^{3}\right)$ & 1.86 & $3.09^{*}$ \\
\hline Thickness $(\mu \mathrm{m})$ & 57.27 & $38.06^{*}$ \\
\hline Keratin thickness $(\mu \mathrm{m})$ & 11.19 & $7.06^{*}$ \\
\hline Outer/inner surface ratio & 0.85 & $1.01^{* *}$ \\
\hline Number density $\left(\mathrm{n} / \mathrm{mm}^{3} \times 10^{6}\right)$ & 0.93 & $1.66^{*}$ \\
\hline
\end{tabular}

* Statistically significant at $\mathrm{p}<0.01 .{ }^{* *}$ Statistically significant at $\mathrm{p}<0.05$.

\section{CONCLUSIONS}

Intoxication caused by cadmium in pups during lactation led to slowed growth and reduced body weight. The epithelium of the floor of the mouth was significantly thinner, with smaller and more numerous cells, showing cell hypotrophy.

\section{ACKNOWLEDGMENTS}

This study was supported by grants from CNPq (National Council for Scientific and Technological Development) and UNIFRAN (University of Franca).

2. Biggart NW, Murphy EC Jr. Analysis of metal-induced mutations altering the expression or structure of a retroviral 
Picoli LC, Watanabe I, Lopes RA, Sala MA, Picoli F. Effect of cadmium on the floor of the mouth on rats during lactation. Braz Oral Res 2004;18(2):105-9.

gene in a mammalian cell line. Mutat Res 1988;198:11529.

3. Britton RS, Tavill AS, Bacon BR. Mechanisms of iron toxicity. In: Brock JH, Halliday JW, Pippard MJ. Iron metabolism in health and disease. London: Saunders; 1994. p. 311-51.

4. Cheng L. The concept of direct and indirect neurotoxicity and the concept of toxic metal/essential element interactions as a common biomechanism underlying metal toxicity. Bull Brain Environ Risks 1992;2:61-82.

5. Coogan TP, Bare RM, Waalkes MP. Cadmium-induced DNA strand damage in cultured liver cells: reduction in cadmium genotoxicity following zinc pretreatment. Toxicol Appl Pharmacol 1992;113:227-33.

6. Crowe A, Morgan EH. Effect of dietary cadmium on iron metabolism in growing rats. Toxicol Appl Pharmacol 1997; 145:136-46.

7. Floris B, Bomboi G, Sechi P, Pirino S, Marongiu ML. Cadmium chronic administration to lactating ewes: reproductive performance, cadmium tissue accumulation and placental transfer. Ann Chim 2000;90:703-8.

8. Gamulin S, Car N, Narancsik P. Effect of cadmium on polyribosome structure and function in mouse liver. Experimentia 1977;33:1144-5.

9. Goyer RA. Toxic effects of metals. In: Doull MO. Doull's toxicology. The basic science of poisons. $4^{\text {th }}$ ed. New York: Pergamon Press; 1991. p. 623-80.

10. Hartwig A. Role of DNA repair inhibition in lead- and cadmium-induced genotoxicity: a review. Environ Health Perspect 1994;102(3 Suppl):45-50.

11. Lijnen P, Staessen J, Fagard R, Amery A. Effect of cadmium on the transmembrane $\mathrm{Na}^{+}$and $\mathrm{K}^{+}$transport systems in human erythrocytes. Br J Ind Med 1991;48:392-8.

12. Loiacomo NJ, Graziano JH, Kline JK, Popavac D, Ahmedi X, Gashi E, et al. Placental cadmium and birthweight in women living near a lead smelter. Arch Environ Health 1992;47:250-5.

13. Lucis OJ, Lucis R, Shaikh ZA. Cadmium and zinc in pregnancy and lactation. Arch Environ Health 1972;25:1422.

14. Miccadei S, Floridi A. Sites of inhibition of mitochondrial electron transport by cadmium. Chem Biol Interact 1993;89:159-67.

15. Morselt AF. Environmental pollutants and diseases. A cell biological approach using chronic cadmium exposure in the animal model as a paradigm case. Toxicology 1991;70:1-32.

16. Panemangalore M, Cherian MG. Metabolism of parenterally administered zinc and cadmium in livers of newborn rats. Chem Biol Interact 1983;45:327-39.
17. Petersson Grawe K, Oskarsson A. Cadmium in milk and mammary gland in rats and mice. Arch Toxicol 2000; 73:519-27.

18. Sala MA, Komesu MC, Lopes RA, Maia Campos G. Karyometric study of basal cell carcinoma. Braz Dent J 1994;5:11-4.

19. Sala MA, Lopes RA, Matheus M. Método morfológico para análisis cuantitativa de los tejidos. Determinación de los parámetros normalis para el hepatocito de rata. Arch Fac Med Zaragoza 1992;32:29-31.

20. Sandstead HH, Gillespie DD, Brady RN. Zinc deficiency: effect on brain of the suckling rat. Pediatr Res 1972;6:119-25.

21. Schafer S, Elsenhans B. Iron retention and distribution in the cadmium-induced iron deficiency. Ecotoxicol Environ Saf 1985;10:128-41.

22. Shamoo AE. Biological target sites of mercurials. In: Eccles CU, Annau $Z$. The toxicity of methyl mercury. Baltimore: Johns Hopkins University Press; 1987. p. 13-23.

23. Stacey $\mathrm{NH}$, Klaassen $\mathrm{CD}$. Cadmium uptake by isolated rat hepatocytes. Toxicol Appl Pharmacol 1980;55:44855.

24. Templeton DM, Cherian MR. Toxicological significance of metallothionein. Methods Enzymol 1991;205:11-24.

25. Visser GJ, Peters PHJ, Theuvenet APR. Cadmium ion is a non-competitive inhibitor of red cell $\mathrm{Ca}^{2+}$-ATPase activity. Biochim Bhiophys Acta 1993;1152:26-34.

26. Vorbrodt AW, Trowbridge RS, Dobrogowska DH. Cytochemical study of the effect of aluminium on cultured brain microvascular endothelial cells. Histochem J 1994;26:11926.

27. Webster WS. Cadmium-induced fetal growth retardation in the mouse. Arch Environ Health 1978;33:36-42.

28. Whelton BD, Bhattacharyya MH, Carnes BA, Moretti ES, Peterson DP. Female reproduction and pup survival and growth for mice fed a cadmium-containing purified diet through six consecutive rounds of gestation and lactation. J Toxicol Environ Health 1988;24:321-43.

29. Wong KL, Klaassen CD. Neurotoxic effects of cadmium in young rats. Toxicol Appl Pharmacol 1982;83:330-7.

30. Yonish-Rouach E, Gnsberg D, Oren M. The role of tumour suppressor genes in apoptosis. In: Lavin $\mathrm{M}$, Waters D. Programmed cell death: the cellular and molecular biology of apoptosis. Chur: Harwood Academic Publishers; 1993. p. $187-203$

Received for publication on Aug 01, 2003 Accepted for publication on Apr 29, 2004 